\title{
Relationship Pattern among Scientific Literacy, Thematic, and Scientific Materials in Online Learning
}

\section{Pola Hubungan antara Literasi Sains, Pembelajaran Tematik dan Saintifik selama Pembelajaran Daring}

\author{
Mohammad Imam Sufiyanto' ${ }^{1}$, Jamilah'², Nisrina Hikmawati ${ }^{3}$ \\ 1IAIN Madura, 2STIKIP PGRI Sumenep, 3INKADHA Sumenep \\ 1bersamabiologi@gmail.com, 2jamilah@stikippgrisumenep.ac.id, \\ 3nisrina.hikmawati@gmail.com
}

DOI: $10.18860 /$ mad.v13i2.12020

Abstract. The research of this study to determine the relationship among scientific, thematic learning materials, and scientific literacy integrated in online learning carried out in three different primary schools in Sumenep Regency. Learning science is with a scientific approach in primary school can be meant as student's mastery of knowledge about scientific, thematic, and scientific literacy, which is learned from facts, principles, and the discovery process during online learning. However, the science material given must be adapteded to the age and characteristics of the students concerned, meaning that science material is given to students and adjusted to the grade level, so that mastery of science can be beneficial both for the students and for the natural environment preservation around them. This research uses qualitative descriptive research type with survey approach. The research population was 60 teachers and 280 students from three different schools, while the sample of this study consisted of 30 teachers and 150 students from whom the samples were taken using probability sampling. The data collection techniques in this study were in the forms of questionnaires and interview techniques for the teachers and students to complete the data. The research results showed that there are $71,7 \%$ of students have a low index of scientific literacy. The implementation of thematic and scientific learning which was constrained during the pandemic generally resulted in low student scientific literacy. This is a reference for teachers so that the application of integrative scientific and thematic approaches in learning is more optimal.

Keywords. Scientific literacy; Thematic; Scientific

Abstrak. Riset ini bertujuan untuk mengetahui hubungan antara literasi sains, tematik, dan saintifik yang dipadukan dalam pembelajaran daring serta dilaksanakan di 3 Sekolah Dasar dan Madrasah Ibtidaiyah di Kabupaten Sumenep. Pembelajaran IPA dengan pendekatan saintifik disekolah dasar merupakan kajian pada siswa terhadap pengetahuan tentang literasi sains, tematik, dan saintifik, yang dipelajari dari fenomena, metode, dan teknik eksperimen selama pembelajaran daring. Riset ini menggunakan jenis penelitian deskriptif kualitatif dengan pendekatan survey. Populasi berjumlah 60 orang guru dan 280 siswa dari tiga sekolah yang berbeda, sedangkan sample penelitian ini berjumlah 30 orang guru dan 150 orang siswa yang pengambilan sampelnya menggunakan probability sampling. Teknik pengumpulan data di dalam

Vol. 13 No. 2 Juni 2021 
penelitian ini menggunakan angket dan kuisioner, serta untuk melengkapi data menggunakan teknik wawacara terhadap guru dan siswa. Hasil penelitian menunjukkan bahwa $71,7 \%$ siswa memiliki kemampuan literasi sains rendah. Pelaksanaan pembelajaran tematik dan saintifik yang terkendala selama pembelajaran daring menjadi penyebab rendahnya indeks literasi sains siswa. Hal ini menjadi referensi bagi guru sehingga penerapan pendekatan saintifik dan tematik integratif dalam pembelajaran lebih optimal.

Kata Kunci. Literasi Sains; Tematik; Saintifik

Received: 21-04-2021

Approved: 24-05-2021

Revised: 08-05-2021

Published: 09-06-2021

Copyright (C) Madrasah Jurnal Pendidikan dan Pembelajaran Dasar. All Right Reserved. This is an open access article under the CC BY-SA license

(Creative Commons Attribution-ShareAlike 4.0 International License.)

Correspondence Address: jamilah@stikippgrisumenep.ac.id

\section{A. PENDAHULUAN}

Pembelajaran sains membutuhkan suatu budaya literasi sains, yang dikemas dalam kajian metode tematik dan dengan pendekatan saintifik. Mengacu pada data PISA, dimana siswa sekolah dasar memiliki kemampuan belajar yang kurang dengan indikatornya adalah keterampilan literasi, matematika dan sains siswa. Dapat diamati pada tahun 2019, yakni hanya 30\% siswa yang memiliki kompetensi literasi sains di atas rata-rata. Artinya, sebanyak $70 \%$ siswa kompetensi literasinya sangat kurang. Sedangkan dalam keahlian berhitung (matematika), ditunjukkan hanya $29 \%$ siswa yang kemampuannya di atas minimum. Artinya, sebanyak $71 \%$ siswa itupun berada pada titik minimum. Kita juga dapat mengamati bahwa $60 \%$ siswa di bawah standar kompetensi untuk keterampilan sains. Skor PISA Indonesia selama kurun waktu 10-15 terakhir masih tetap sama, yang berarti tidak peningkatan yang berarti dalam pendidikan dan kemampuan belajar siswa (OECD, 2019; Setiawan, 2019; 2017; Utari, Karim, Prima, Saepuzaman, \& Nugaha, 2017; OECD\&ADB, 2015; Naturasari, Roshayanti, \& Nurwahyunani, 2016; Adisendjaja, 2008). Pada tingkat satuan dasar budaya literasi sains berupa penyajian data penelitian, hasil eksperimen, dan penguasaan teknis prosedur dalam penelitian tidak disajikan dalam kajian tematik dan pendekatan saintifik. Hasil berupa kajian dalam proses pembelajaran tematik dengan pendekatan serta membudayakan literasi sains dapat menampilkan bahwa pendekatan tematik bisa dijadikan sarana untuk melatih siswa agar memiliki kemampuan literasi sains dimana pada abad 21 inilah dibutuhkan keterampilan dalam literasi sains tersebut (Setiawan, 2020:69).

Upaya dalam membangun literasi sains siswa dalam pembelajaran, telah banyak dilakukan oleh para pendidik dan juga diteliti oleh para peneliti di tanah air. Utari, Karim, Prima, Saepuzaman, \& Nugraha (2017:65) melakukan penelitian di tingkat pendidikan sekolah dasar, khususnya mata pelajaran IPA dengan tema lingkungan. Diperoleh data bahwa siswa menjadi kurang kritis dan tidak memberikan solusi terhadap hasil percobaan yang dilakukan pada pembelajaran tatap muka. walaupun sebagian besar siswa mampu menyusun langkah eksperimen dan tabel pengamatan,

Vol. 13 No. 2 Juni 2021 


\section{MADRASAH}

Jurnal Pendidikan dan Pembelajaran Dasar

p ISSN: 1979-5599 | e ISSN: 2502-194X

Pag e

serta mengajukan pertanyaan terkait pembelajaran (Rahmadona \& Astimar, 2017). Data penelitian tersebut juga memberikan gambaran dimana kemampuan siswa dalam studi dapat lebih berkembang dengan diterapkannya metode tematik terpadu dan pendekatan saintifik dalam menstimulasi keaktifan siswa (Sutmala \& Harni, 2020:2).

Berbagai penelitian tersebut ternyata banyak dilakukan terhadap siswa pada pembelajaran tatap muka sebelum pandemi. Analisis terhadap penelitian tentang penerepan tematik dengan metode saintifik di tingkat sekolah dasar belum banyak diinformasikan selama masa pandemi berlangsung. Untuk itulah sangat penting dalam mengembangkan keterampilan siswa melalui kegiatan literasi sains dengan tematik berbasis saintifik. Pengambangan ini perlu dimulai sedini mungkin pada level atau jenjang sekolah dasar yang merupakan tahap pertama dari siklus dalam pembelajaran siswa di sekolah dimasa pandemi. Lebih mudah dan efektif untuk membiasakan menerapkan listerasi sains pada anak usia SD atau sedini mungkin, karena tingkat kerumitan tematik berbasis saintifik dalam pembelajaran jauh lebih mudah dilakukan dibandingkan dengan siswa menengah dan atas atau orang yang lebih tua (Setiawan \& Saputri, 2020).

Pemahaman terkait metode tematik, dan saintifik untuk meningkatkan literasi sains dimasa pandemi dengan menerapkan beberapa domain kompetensi pada literasi sains yaitu menjelaskan problem, menafsirkan data, mengkomunikasikan data, merencanakan penyelidikan, melakukan penyelidikan, dan mengevaluasi penyelidikan ilmiah. Dari beberapa domain kompetensi, berdasarkan kajian konsep dan temuan peneliti sebelumnya, maka perlu melakukan penelitian hubungan antara literasi sains, tematik, dan saintifik. Dengan demikian penelitian ini diharapkan mampu menjadi tambahan informasi penelitian di masa pandemi, terutama untuk memetakan kemampuan literasi sains siswa pendidikan dasar di masa pandemi. Selain itu karena kajian pembelajaran sains di tingkat satuan dasar terbatas, sehingga perlu memiliki kajian lebih lanjut.

Berdasarkan pemaparan dan analisis kebutuhan, maka riset ini bertujuan untuk mendeskripsikan pola hubungan antara model pembelajaran tematik, dan saintifik untuk meningkatkan literasi sains dimasa pandemi pada tingkat satuan sekolah dasar (SD) yakni utamanya pada mata pelajaran IPA SD, karena ditengah pandemi seperti pada masa sekarang pembelajaran IPA SD sangat sulit dilakukan tanpa adanya kegiatan dari praktikum (praktek) dan eksperimen yang dilakukan untuk menguji suatu fenomena atau membuktikan sebuah teori.

Perubahan masyarakat merupakan salah satu yang mendasari pengembangan konsep dari model pembelajaran tematik, dan saintifik, untuk meningkatkan literasi sains termasuk perkembangan teknologi informasi di era saat ini, kelahiran ekonomi global, dan era distruption, sehingga perlu dipersiapkan sejak dini tantangan global pada pembelajaran disekolah dasar. Penelitian ini perlu dilakukan sebab, dengan melibatkan model pembelajaran tematik, dan saintifik, sehingga dapat melatih siswa untuk memiliki kemampuan literasi sains dan terlibat langsung dalam problem keseharian yang berhubungan dengan kegiatan sains. Selain itu mampu menggunakan ide-ide pada sains untuk berperan serta secara reflektif sebagai warga negara dalam menyelesaikan permasalahan. Hal ini membutuhkan kompetensi antara lain

Vol. 13 No. 2 Juni 2021 
menjelaskan kejadian berdasarkan proses berpikir ilmiah, melakukan evaluasi dan merencanakan eksperimen ilmiah, juga menguraikan data dan bukti menggunakan metode ilmiah (Setiawan, 2019).

Saat ini Indonesia menerapkan kurikulum 2013 dalam melaksanakan strategi pendidikan, dimana kurikulum tersebut memiliki karakter salah satunya yaitu mengintegrasikan langkah tematik dan saintifik dalam kegiatan belajar. Saintifik merupakan salah satu pendekatan studi yang menjelaskan konsep tentang sistematika ilmiah dalam mengamati dan menyelesaikan suatu masalah secara umum. Kegiatan belajar dengan menggunakan pendekatan saintifik tentu membutuhkan metode yang sesuai dan tepat (Nurul Ain, 2018, hlm 1). Metode yang dimaksud adalah metode pembelajaran yang menitikberatkan pada stimulasi siswa untuk melakukan proses penyingkapan/penelitian (discovery/inquiry learning) dalam kegiatan belajar, sesuai dengan permendikbud No 65 tahun 2013. Berdasarkan permendikbud tersebut, maka terdapat tiga jenis metode yang digunakan yaitu metode Discovery Learning, metode Inquiry Based Learning, dan Problem Based Learning, dimana langkah-langkah saintifik selalu diterapkan dalam pelaksanaan metode tersebut.

Untuk mencapai tujuan tersebut, maka penerapan pembelajaran IPA harus dilakukan secara terstruktur dan terukur. Struktur pembelajaran yang dirancang dengan langkah-langkah yang tepat, sehingga memudahkan dalam mengevaluasi dan mengukur hasil yang dicapai. Dalam hal ini pembelajaran dapat dilakukan dengan beragam inovasi seperti menggunakan tematik dan pendekatan saintifik untuk peningkatan literasi sains (Setiawan, 2019, hlm. 8) Langkah-langkah kegiatan pembelajaran dengan pendekatan saintifik secara berurutan, yaitu mengamati suatu topik, menanya tentang topik yang sesuai, serta mengumpulkan informasi untuk membangun konsep tentang topik tersebut, melakukan eksperimen, memproses data hasil eksperimen, serta mengomunikasikan penemuan agar dapat dipahami oleh orang lain (Setiawan, 2019, hlm. 2).

\section{B. METODE PENELITIAN}

Penelitian ini termasuk deskriptif kualitatif menggunakan pendekatan survey. Metode dekriptif kualitatif digunakan untuk menggali berbagai fenomena di lapangan yang terjadi secara langsung atau pada saat sekarang ini berdasarkan pada data yang ditemukan serta bagaimanaa hubungan literasi sains, pembelajaran tematik dengan pendekataan saintifik dalam pembelajaran daring selama pandemi Covid 19. Pendekatan survei (Hanafi, 2017), untuk mengetahui pelaksanaan literasi sains, pembelajaran tematik, dan saintifik dari siswa serta menganalisa hubungan antara ketiga hal tersebut.

Subjek penelitian adalah 280 orang siswa di tiga tempat berbeda yaitu MI AlIkhlas, Sekolah Dasar Integral Luqman Al hakim, dan di Madrasah Ibtidaiyah Negeri (MIN) 1 Sumenep. Data dikumpulkan melalui wawancara, angket, observasi serta dokumentasi. Interview (wawancara) kepada siswa tentang (a) keaktivan siswa dalam literasi sains berbasis tematik dan (b) bagaimana pemahaman siswa terhadap literasi sains dalam saintifik. Data dokumentasi diperoleh melalui (a) perangkat pembelajaran seperti silabus, media pembelajaran (b) Dokumen hasil pembelajaran dengan tematik berupa hasil penilaian harian dan buku prestasi siswa dengan interval waktu pengamatan mulai Maret 2020 hingga Februari 2021.

Vol. 13 No. 2 Juni 2021

Madrasah homepage: http://ejournal.uin-malang.ac.id/index.php/madrasah/index 


\section{MADRASAH}

Jurnal Pendidikan dan Pembelajaran Dasar

p ISSN: 1979-5599 | e ISSN: 2502-194X

Penilaian angket atau kuesioner digunakan untuk melihat bagaimana siswa dan guru menilai literasi sains, tematik dan saintifik. Angket penilaian pembelajaran berupa tes penguasaan konsep literasi sains, tematik serta tes saintifik selama pembelajaran daring di era pandemi. Hal ini digunakan agar diperoleh gambaran menyeluruh tentang pelaksanaan pembelajaran di sekolah pada masa pandemi dengan model literasi sains, tematik, dan saintifik.

Metode observasi meliputi: (a) bagaimana cara mengimplementasi literasi sains terhadap pembelajaran tematik, (b) peserta didik senang selama proses pembelajaran, (c) peserta didik mempunayai kemampuan berfikir dengan pola literasi sains berbasis saintifik. Dokumentasi dalam penelitian digunakan untuk memperkuat hasil penelitian seperti: (a) media kegiatan pembelajaran literasi sains, tematik, dan saintifik (b) dokumentasi kegiatan guru dan peserta didik dengan literasi sains, tematik, dan saintifik (c) record hasil wawancara dengan pendidik dan peserta didik.

Proses analisa data dalam riset ini dilakukan berdasarkan metode kualitatif dan metode kuantitatif (Syaifuddin, 2017). Tahapan-tahapan untuk menganalisis data riset yaitu reduksi (data reduction), penyajian (data display), dan verifikasi (conclusion drawing/verification) (Williamson et al., 2017). Mereduksi data artinya merangkum berbagai hasil penelitian, memilih bagian yang terpenting dari penelitian seperti tema penelitian. Sehingga hasil reduksi data menghasilkan penelitian valid, serta memudahkan peneliti untuk pengambilan data selanjutnya. Langkah berikutnya adalah display data.

Bentuk penyajian data penelitian ini berupa grafik atau tabel, dan uraian singkat. Sehingga data menjadi tersusun sesuai fokus penelitian yang bersifat deskriptif. Verifikasi data merupakan kesimpulan sementara dari hasil penelitian dan bisa berubah jika ditemukan bukti lain yang kuat dalam pengumpulan data. Analisis kualitatif berupa saran perbaikan dalam pembelajaran literasi sains, tematik, dan saintifik oleh guru, serta orang tua. Analisis data kuantitatif diperoleh melalui teknik perhitungan persentase mengenai keterlaksanaan model pembelajaran serta penilaian terhadap siswa dalam pembelajaran sains dengan pendekatan tematik (Jamilah, 2020).

\section{HASIL PENELITIAN DAN PEMBAHASAN}

Penelitian ini menggambarkan berbagai data tentang penerapan tematik, pengintegrasian saintifik dalam pembelajaran dan tingkat kompetensi literasi siswa di tiga SD dan MI di Kabupaten Sumenep. Hasil tersebut dianalisa melalui teknik perhitungan persentase, kemudian dipaparkan secara kualitatif untuk memperoleh pemahaman yang komprehensif, tentang pola hubungan literasi sains, tematik dan saintifik dalam pembelajaran selama pandemi covid-19.

Vol. 13 No. 2 Juni 2021 


\section{Penerapan Metode Tematik Berbasis Saintifik}

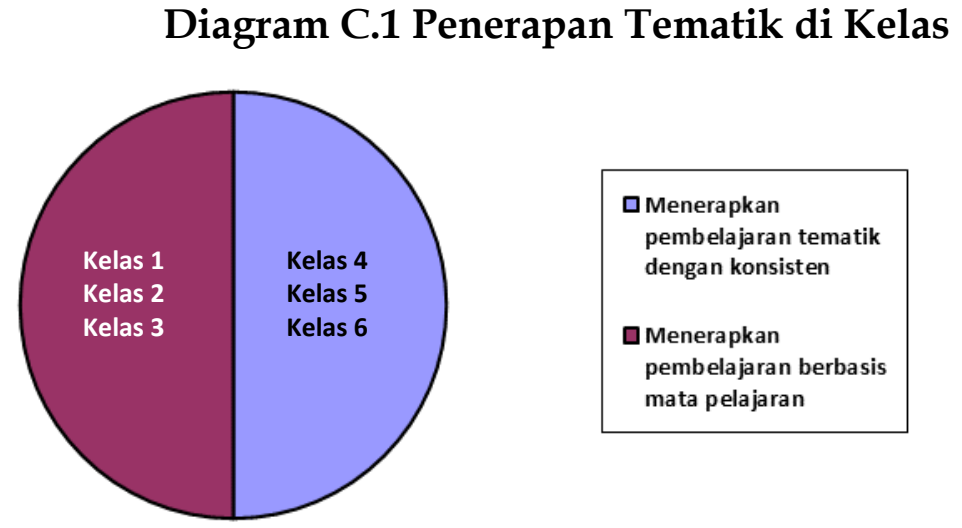

Sumber: Dokumen peneliti, 2021

Hasil dari penyebaran angket terhadap 30 orang guru kelas pada 3 SD dan MI di Kabupaten Sumenep menunjukkan bahwa, penerapan pembelajaran tematik dilakukan secara konsisten di kelas 1 sampai kelas 3 . Sementara itu untuk kelas 4 sampai kelas 6 menerapkan pembelajaran berbasis mata pelajaran.

\section{Diagram C.2 Pengintegrasian Saintifik dalam Pembelajaran}
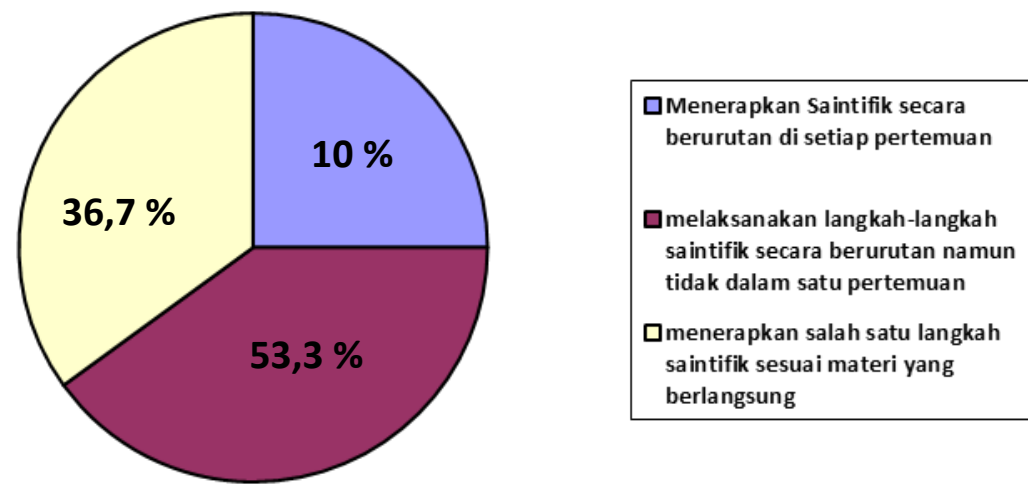

Sumber: Dokumen Peneliti, 2021

Sedangkan untuk penerapan Pendekatan saintifik yang merupakan dasar dari pelaksanaan pembelajaran tematik, telah dapat dilaksanakan oleh semua guru di tiga sekolah tersebut. Namun peneliti mengkategorikan menjadi 3 kelompok, pertama sebesar $10 \%$ yaitu 3 orang guru yang melaksanakan langkah-langkah saintifik secara berurutan di setiap pertemuan yang telah direncanakan, kedua 36,7 \% yaitu 11 orang guru yang melaksanakan langkah-langkah dalam saintifik secara berurutan namun tidak dalam satu pertemuan, ketiga 53,3\% yaitu 16 orang guru menerapkan salah satu langkah saintifik sesuai materi yang berlangsung.

Berdasarkan pada Permendikbud RI Nomor 24 Tahun 2016 disebutkan bahwa pelaksanaan kegiatan belajar di pendidikan dasar dilakukan dengan menerapkan tematik sebagai model pembelajarannya (Kemdikbud, 2016) yaitu dengan memilih tema-tema khusus yang dapat memadukan beberapa konsep untuk mempelajari suatu topik yang telah ditentukan (Resor, 2017; Seefeldt, 2005). Berdasarkan informasi dari

Vol. 13 No. 2 Juni 2021 


\section{MADRASAH}

Jurnal Pendidikan dan Pembelajaran Dasar

tiga kepala sekolah di sekolah dasar yang berbeda, bahwa kegiatan belajar mengajar di kelas satu sampai kelas enam telah menerapkan pembelajaran tematik sejak tahun 2018 dimana sebelumnya masih bertahap peralihan dari KTSP ke Kurikulum 2013. Kepala sekolah juga telah menginstruksikan kepada seluruh dewan guru untuk melaksanakan pembelajaran sebagaimana tuntutan dalam kurikulum 2013, yaitu menggunakan pembelajaran tematik dan pendekatan saintifik, meskipun ditengah pandemi yang tengah berlangsung.

Hal ini ditunjukkan dengan dirancangnya perangkat pembelajaran oleh setiap guru berupa silabus dan RPP menggunakan pembelajaran tematik. Tahapan-tahapan pendekatan saintifikpun telah tercantum dalam RPP secara konsisten dan dilakukan pengawasan secara berkala.

Berdasarkan wawancara dengan guru, RPP yang digunakan oleh guru dalam pembelajaran berupa tema-tema yang ada dalam pedoman rencana pelaksanaan pembelajaran di kelas terutama dalam pembelajaran sains. Penggunaan tema disesuaikan dengan kehidupan nyata siswa di rumah maupun di sekolah. Temuan dalam penelitian ini sesuai dengan pendapat (Trianto, 2010) bahwa penerapan tema yang dilakukan oleh guru dari lingkungan yang paling dekat dengan siswa, siswa memahami lingkungan sekitarnya dan sesuai dengan ruang lingkup perkembangan siswa dalam memahami lingkungan sekitar.

Namun dalam pelaksanaannya, khususnya pada masa pandemi ini guru mengalami beberapa kesulitan untuk menerapkan tematik dan saintifik. Para guru berpandangan, kesulitan dalam menerapkan pembelajaran tematik karena adanya beberapa hal berikut ini:

a. Guru belum sepenuhnya memahami tentang pembelajaran tematik sehingga belum bisa menerapkan secara konsisten

b. Penilaian hasil belajar siswa yang berupa raport, tidak berbasis tema melainkan berbasis mata pelajaran. Sehingga guru tetap harus memilah-milah dalam melakukan penilaian hasil belajar siswa berdasarkan mata pelajaran.

c. Penerapan pembelajaran secara daring tidak memungkinkan untuk menggunakan tematik maupun saintifik.

Sedangkan Kesulitan-kesulitan dalam mengintegrasikan saintifik dalam pembelajaran pada saat daring disebabkan karena adanya beberapa hal, yaitu:

a. Beberapa guru memang belum siap menerapkan pembelajaran tematik berbasis saintifik. Kurangnya pemahaman guru terhadap metode pembelajaran tematik berbasis saintifik menjadi penyebab terbesar tidak terlaksananya metode ini. Jadi kebanyakan guru menyampaikan materi dengan metode ceramah atau demonstrasi, apalagi kurangnya praktikum dalam pelaksanaan pembelajaran daring.

b. Kurang mendapatkan dukungan dari orang tua siswa (wali murid). Inovasi pembelajaran selama daring, misalkan penggunaan video pembelajaran, zoom, atau google classroom, seringkali tidak disepakati oleh orangtua siswa. Kebanyakan beralasan tidak bisa untuk mendampingi putra putrinya selama pembelajaran karena bekerja dan orang tua tidak jujur dengan mengerjakan tugas putra-putrinya, tanpa didampingi.

Vol. 13 No. 2 Juni 2021 
c. Keterbatasan sarana, seperti HP dan jaringan internet yang ada di rumah. Beberapa orangtua siswa juga mengeluhkan keterbatasan HP baik itu tidak support aplikasinya maupun tidak mampu menyediakan kuota internetnya pada saat pembelajaran yang berlangsung setiap minggunya.

d. Perbedaan dari kemampuan para siswa pada tiga sekolah yang disurvey. Siswa dengan kemampuan akademik yang baik, dapat mengikuti pembelajaran daring dengan baik pula. Namun siswa yang kesulitan, tidak dapat memahami materi yang disampaikan melalui zoom maupun grup whatsapp (WAG).

Beragamnya permasalahan tersebut menjadi alasan pihak sekolah mengambil kebijakan bahwa pembelajaran tematik dilaksanakan secara konsisten di kelas rendah yaitu 1 sampai 3. Sedangkan untuk kelas tinggi yaitu 4 sampai 6, materi tetap menggunakan RPP dan buku panduan terkait tematik, dan saintifik, namun dibuatkan jadwal khusus dari kegiatan belajar mengajar per mata pelajaran. Keputusan ini diambil oleh Tiga Sekolah yang berbeda dalam rangka melaksanakan KBM dengan baik, dan untuk mencapai kompetensi siswa yang diharapkan.

Untuk pelaksanaan pendekatan saintifik dalam pembelajaran, tetap dilakukan oleh guru. Namun hanya 10\% guru kelas yaitu 3 orang yang menerapkan langkahlangkah saintifik secara berurutan dalam setiap pertemuannya. Langkah-langkah tersebut tercantum dalam RPP guru meliputi, (a) Ayo membaca (Mengamati), (b) Ayo berdiskusi (Menanya dan Mencari informasi), dan (c) Ayo berlatih (Mengolah data, Melakukan percobaan dan mengkomunikasikan).

Siswa dibimbing untuk terbiasa melakukan cara sistematis. Prosedur ilmiah merupakan skill (kemampuan khsusus) yang harus dimiliki untuk mewujudkan sebagai peneliti (Karsai \& Kempis, 2010: 634). Kegiatan pembelajaran dengan aktifitas saintifik yang mampu meningkatkan keterampilan tersebut harus diberikan kepada siswa, dengan harapan siswa mampu "menemukan" konsep-konsep dan melakukan eksperimen dengan cara ilmiah yang benar. Metode - metode pembelajaran yang mengintegrasikan langkah-langkah saintifik dalam prosesnya, secara significant dapat mengembangkan daya nalar, dan pemahaman siswa terhadap pembelajaran (Argaw, dkk (2017), Abdi, (2014), membantu siswa untuk lebih kritis dalam berpikir (Nafisah dan Suyanto, 2014), dan lebih kreatif serta inovatif (Nicholes dan Stephens, 2013).

Sisanya 90\%, yaitu 27 orang guru melakukan pendekatan saintifik dalam pembelajaran disesuaikan dengan kondisi dan materi saat itu, sehingga tidak harus berurutan. Hal ini berkaitan dengan keterampilan proses yang dapat dipilih oleh guru sesuai dengan topik dan pelajaran yang dipersiapkan (Ain \& Huda, 2018), memberikan informasi secara berkala dan berkesinambungan sehingga diharapkan nantinya akan terbentuk mindset prosedur keterampilan yang lebih utuh, sehingga dapat melakukan percobaan yang simpel (Darmodjo \& Kaligis, 1991: 11).

\section{Identifikasi Literasi Sains Siswa}

Berdasarkan instrumen yang disebarkan kepada guru, dapat ditemukan bahwa sejumlah guru belum memahami tentang yang dimaksud dengan literasi sains serta guru tidak mengamati kemampuan literasi sains siswa. Sebagian besar dengan persentase $80 \%$ guru yaitu 24 orang tidak mengisi lembar penilaian literasi sains siswa dengan keterangan belum memahami dan belum melaksanakan. Sedangkan sisanya sebesar $20 \%$ yaitu 6 orang guru melakukan pengamatan tersebut kadang-kadang.

Vol. 13 No. 2 Juni 2021 


\section{Diagram C.3 Identifikasi Kemampuan Literasi Sains Siswa Oleh Guru}

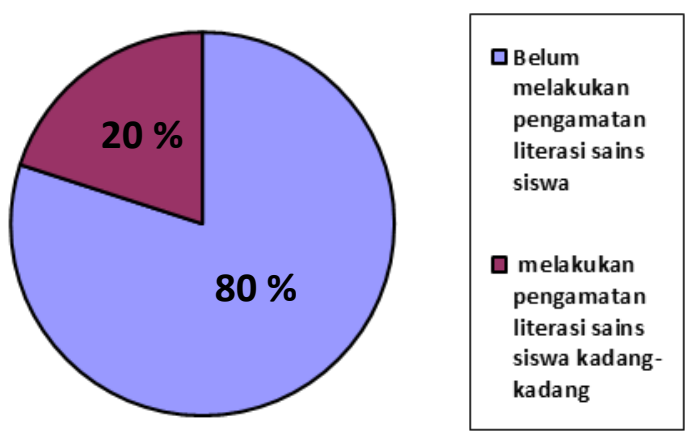

Sumber: Dokumen peneliti 2021

Enam orang guru kelas melakukan pengamatan terhadap literasi sains siswa, yang berarti terdapat 6 kelas dengan jumlah siswa 105 anak. Hasil dari pengamatan tersebut, peneliti hanya menampilkan persentase siswa dengan kompetensi literasi sains dalam kategori bagus, artinya nilai lebih dari 3 dalam skala 1-4. Penilaian tersebut dilakukan pada tiap indikator yang diadopsi dari Setiawan (2020). Berikut ini data penilaian tersebut:

\section{Tabel C.1 Hasil Identifikasi Literasi Sains Siswa}

\begin{tabular}{|c|c|c|}
\hline Domain Kompetensi & Indikator Literasi Sains & $\begin{array}{c}\text { Persentase } \\
\text { Jumlah Siswa }\end{array}$ \\
\hline $\begin{array}{l}\text { Menjelaskan masalah } \\
\text { secara ilmiah }\end{array}$ & $\begin{array}{l}\text { - Mengkaji beberapa teknik/metode } \\
\text { ilmiah yang sesuai } \\
\text { - Menata persoalan didasarkan } \\
\text { dengan kajian masalah }\end{array}$ & $29,5 \%$ \\
\hline $\begin{array}{l}\text { Menafsirkan data } \\
\text { secara ilmiah }\end{array}$ & $\begin{array}{l}\text { - Menata kembali data menggunakan } \\
\text { kajian sesuai fakta } \\
\text { - Meneliti data dan kumpulan pesan } \\
\text { dari setiap kajian Interpretasi } \\
\text { pemikiran }\end{array}$ & $19 \%$ \\
\hline $\begin{array}{l}\text { Mengomunikasikan } \\
\text { data secara ilmiah }\end{array}$ & $\begin{array}{l}\text { Meringkas data ilmiah atas dasar } \\
\text { penyelidikan } \\
\text { Menjelaskan manfaat dari } \\
\text { pengetahuan ilmiah (sains) bagi } \\
\text { masyarakat }\end{array}$ & $40 \%$ \\
\hline $\begin{array}{l}\text { Merencanakan } \\
\text { pelacakan ilmiah }\end{array}$ & $\begin{array}{l}\text { - Menetapkan variabel penyelidikan } \\
\text { - Mengajukan metode penjajakan } \\
\text { secara prosedural terhadap masalah } \\
\text { yang diberikan }\end{array}$ & $29.5 \%$ \\
\hline
\end{tabular}

Vol. 13 No. 2 Juni 2021 


\begin{tabular}{|l|l|c|}
\hline Domain Kompetensi & \multicolumn{1}{c|}{ Indikator Literasi Sains } & $\begin{array}{c}\text { Persentase } \\
\text { Jumlah Siswa }\end{array}$ \\
\hline $\begin{array}{l}\text { Melakukan } \\
\text { penyelidikan ilmiah }\end{array}$ & $\bullet \begin{array}{l}\text { Memilih cara dan menentukan } \\
\text { representasi secara sistematis } \\
\text { Mampu memilah asumsi, fakta dan } \\
\text { penalaran dalam studi }\end{array}$ & $\mathbf{3 3 \%}$ \\
\hline pengevaluasi & $\bullet \begin{array}{l}\text { Mengevaluasi metode kajian ilmiah } \\
\text { yang dipilih untuk menyelesaikan } \\
\text { permasalahan } \\
\text { Mengevaluasi pendapat dan fakta } \\
\text { ilmiah dari berbagai sumber }\end{array}$ & $\mathbf{1 9 \%}$ \\
\hline
\end{tabular}

Sumber: Peneliti dalam 3 sekolah dasar yang berbeda

\section{a) Menjelaskan masalah secara ilmiah}

Sebanyak $29,5 \%$ atau 31 orang siswa sudah mampu menjelaskan masalah secara ilmiah dengan indikator dapat mengkaji beberapa teknik/metode ilmiah yang sesuai dan menata persoalan didasarkan dengan kajian masalah saat materi diberikan oleh guru. Artinya siswa memahami materi yang diberikan dan mampu mengajukan pertanyaan secara ilmiah tentang materi yang belum dipahami atau membutuhkan tambahan penjelasan dari guru. Siswa-siswa ini tersebar dari berbagai tingkat kelas dari kelas 3-6.

\section{b) Menafsirkan data secara ilmiah}

Sebanyak $19 \%$ atau 20 orang siswa mampu menafsirkan data secara ilmiah dengan indicator Menata kembali data menggunakan kajian sesuai fakta dan meneliti data dan kumpulan pesan dari setiap kajian Interpretasi pemikiran. Dalam hal ini siswa mampu menyajikan data berupa table atau diagram dari sejumlah data, kemudian mampu mendeskripsikannya secara benar. Siswa tersebut terdiri dari kelas 4, 5, dan 6 .

\section{c) Mengomunikasikan data secara ilmiah}

Sebanyak $40 \%$ atau 42 orang siswa mampu mengomunikasikan data secara ilmiah dengan indicator Meringkas data ilmiah atas dasar penyelidikan dan menjelaskan manfaat dari pengetahuan ilmiah (sains) bagi masyarakat. Siswa mampu mempresentasikan dengan baik materi yang diberikan, dan menyimpulkan materi dengan benar. Siswa tersebut terdiri dari kelas 3, 4, 5 dan 6.

\section{d) Merencanakan pelacakan ilmiah}

Sebanyak 29,5\% yaitu 31 orang siswa mampu merencanakan pelacakan ilmiah dengan indikator menetapkan variabel penyelidikan dan mengajukan metode penjajakan secara prosedural terhadap masalah yang diberikan. Dalam hal ini mampu memilih metode yang tepat walaupun sederhana dalam menyelesaikan pertanyaan-pertanyaan dari guru.

\section{e) Melakukan penyelidikan ilmiah}

Persentase sebesar 33\% siswa mampu melakukan penyelidikan ilmiah dengan indikator memilih cara dan menentukan representasi secara sistematis dan mampu memilah asumsi, fakta dan penalaran dalam studi. Dalam hal ini

Vol. 13 No. 2 Juni 2021 


\section{MADRASAH}

Jurnal Pendidikan dan Pembelajaran Dasar

p ISSN: 1979-5599 | e ISSN: 2502-194X

Page

siswa bersemangat dalam melakukan penelitian. Mulai dari melakukan penelusuran referensi baik dari buku-buku bacaan serta internet, lalu membentuk model representasi secara mandiri serta berpikir rasional untuk menyelesaikan eksperimen yang ditugaskan oleh guru. Siswa berasal dari kelas 4, 5 dan 6.

\section{f) Mengevaluasi penyelidikan ilmiah}

Pada persentase sebesar 19\% yaitu 20 orang siswa mampu Mengevaluasi penyelidikan ilmiah dengan indikator mengevaluasi metode kajian ilmiah yang dipilih untuk menyelesaikan permasalahan dan mengevaluasi pendapat dan fakta ilmiah dari berbagai sumber, maksudnya mengevaluasi bentuk menggali secara sains terhadap persoalan yang diberikan dan merefleksi argument dan bukti ilmiah dari beragam model kajian. Dalam hal ini siswa aktif bertanya dan berdiskusi dengan guru terkait benar atau tidaknya cara mereka melakukan penelitian, setelah mencarinya di buku atau internet. Siswa berasal dari kelas 5 dan 6.

Berdasarkan pengamatan terhadap 6 indikator literasi saintifik pada siswa MI Al Ikhlas, SD Integral Luqman Al-hakim, MIN 1 Sumenep diperoleh rata-rata hanya $28,3 \%$ siswa yang memiliki kemampuan literasi saintifik yang baik. Rendahnya kompetensi ini karena proses pembelajaran tematik berbasis saintifik yang diprogramkan sekolah tidak dapat terlaksana dengan baik saat pembelajaran daring.

Pembelajaran tematik berbasis saintifik dibutuhkan penerapan model pembelajaran yang tepat sasaran. Menurut Asih W dalam Nisrina (2020) Terdapat beberapa model pembelajaran untuk materi IPA yang direkomendasikan dalam kurikulum 2013 yaitu:

a. Pembelajaran Penemuan (Inquiry Based Learning),

b. Pembelajaran Penyingkapan (Discovery Learning),

c. Pembelajaran Berbasis Projek (Project Based Learning),

d. Pembelajaran Berbasis Masalah (Problem Based Learning),

e. Pembelajaran Kooperatif (Cooperatif Learning),

f. Pembelajaran Kontekstual (Contextual Learning),

g. Pembelajaran Iqra

h. Pembelajaran Direct Instruction (DI)

i. Pembelajaran SETS (Sience, Environment, Technology, Society).

Selama pembelajaran daring, guru tidak mampu menggunakan model-model pembelajaran tersebut secara optimal, karena beberapa hal antara lain, kurangnya dukungan orang tua, kurangnya kesiapan guru dan kurangnya kesiapan siswa mengikuti pembelajaran selama daring. Kemampuan guru dalam melakukan inovasi dalam pembelajaran berpengaruh terhadap kemampuan literasi siswa (A Sujana, 2019).

\section{Hubungan Literasi Sains, Tematik dan Saintifik}

Merupakan kebijakan yang diregulasikan oleh pemerintah terkait penerapan tematik dipendidikan dasar, serta pendekatan yang direkomendasikan yaitu saintifik. Secara konsep hal tersebut mengandung tahap-tahap ilmiah yang mampu melatih

Vol. 13 No. 2 Juni 2021 
keterampilan literasi sains siswa. I Karsai dan G Kampis (2010) menyatakan bahwa pendekatan saintifik merupakan dasar utama dalam mengembangkan literasi sains.

Seperti yang dipahami bersama bahwa kemampuan literasi sains siswa Indonesia pada level rendah, dan salah satu keuntungan penerapan tematik dan saintifik dalam pembelajaran adalah dapat mengasah keterampilan literasi sains siswa. Bila keterampilan ini terbentuk dalam diri siswa, maka siswa akan terbiasa untuk berfikir dan melakukan penyelidikan dengan cara ilmiah. Keterampilan ini menurut Crawford \& Sen dalam Setiawan (2020) sangat berguna bahkan untuk permasalahan diluar sains, seperti bisnis dan finansial. Mengembangkan keterampilan literasi sains sejak dini, akan sangat membantu siswa menjadi generasi unggul dimasa mendatang yang mampu menyelesaikan berbagai permasalahan secara rasional dan ilmiah. Bukan lagi generasi yang sekedar menduga-duga dengan keterbatasan pemikirannya, melainkan bersemangat untuk menelusuri berbagai ilmu sebagai bukti dan data untuk membuat keputusan dan melahirkan konsep.

Resor (2017) menyatakan model pendekatan tematik adalah model yang proses pembelajarannya menekankan pada tema tertentu yang sudah terpilih dalam mengajarkan beberapa konsep dalam mata pelajaran. Pembelajaran tematik didasarkan dengan cara perpadauan dalam penggunaan berbagai informasi dalam mempelajari topik. Hal senada juga disampaikan Kadir \& Asrohah (2015) ciri pembelajaran tematik adalah metode atau model pembelajaran yang menggabungkan berberapa aspek pembelajaran dalam satu tema atau topik.

Pada pembelajaran tematik perlu dikembangkan dengan adanya langkahlangkah saintifik berupa penyajian data ilmiah, grafik, dan kesimpulan untuk sebuah penelitian agar kemampuan literasi sains siswa bisa terasah. Hal ini dinyatakan sebagai pendekatan saintifik dan tematik integratif.

Gambar C.1 Pendekatan Saintifik dan tematik Integratif

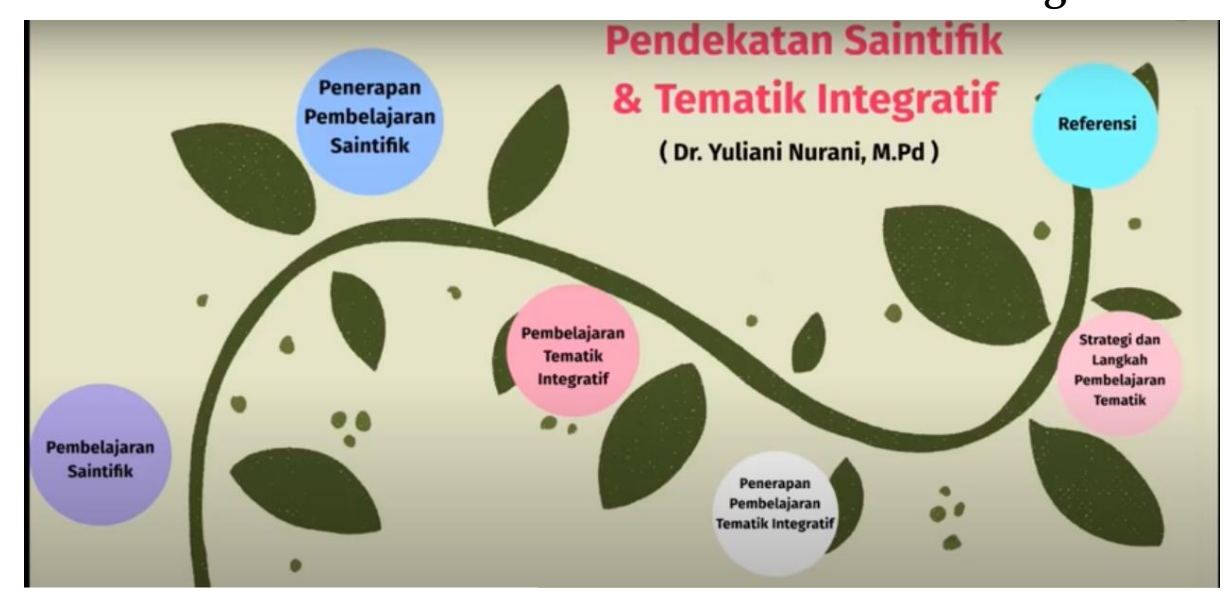

Sumber: Dr. Yuliani Nuraini, M. Pd

Pemaparan sebelumnya telah memberikan gambaran kepada kita mengenai kondisi pelaksanaan literasi sains dan pembelajaran tematik serta saintifik di tiga sekolah dasar selama pandemi berlangsung. Data-data yang ada menunjukkan bahwa semua sekolah tersebut, telah menerapkan kebijakan untuk melaksanakan kegiatan belajar berbasis tematik saintifik meskipun dalam kondisi pandemi.

Namun ada konsekuensi yang harus dihadapi terutama oleh guru dan siswa berinteraksi secara lansung dalam proses pembelajaran di kelas. Ketika pemerintah

Vol. 13 No. 2 Juni 2021

Madrasah homepage: http://ejournal.uin-malang.ac.id/index.php/madrasah/index 


\section{MADRASAH}

Jurnal Pendidikan dan Pembelajaran Dasar

mengeluarkan kebijakan untuk melakukan PJJ (pembelajaran Jarak jauh) atau daring selama pandemi, maka banyak sekali kendala yang dihadapi selama melaksanakan kegiatan belajar berbasis tematik saintifik.

Akibatnya pelaksanaan pembelajaran tematik dan saintifik di tiga SD dan MI di Kabupaten Sumenep, tidak dapat dilaksanakan secara optimal selama pandemi. Setelah dilakukan identifikasi, diperoleh data hanya 28,3\% dari 105 siswa yang memiliki kemampuan literasi sains dengan kategori baik yaitu nilai $>3$ dari skala 1-4. Siswa-siswa tersebut adalah siswa dengan kesiapan yang baik untuk mengikuti pembelajaran daring, diantaranya ada dukungan dari orang tua berupa sarana dan prasarana pendukung belajar anak di rumah selama pandemi. Baik itu berupa HP, laptop dan kuota internet serta buku-buku penunjang juga pendampingan orang tua. Sehingga sebagian program pembelajaran tematik dan saintifik yang diberikan guru mampu dilaksanakan oleh siswa.

Penelitian Xia Jianping (2020) di sekolah dasar di Cina menjelaskan bahwa keluarga yang kooperatif dapat meningkatkan kualitas pembelajaran selama pandemi covid-19 berlangsung. Kerjasama antara sekolah dan orang tua sangat penting sehingga belajar dirumah dan di sekolah tetap terintegrasi.

Sisanya sebesar $71,7 \%$ siswa termasuk kategori kemampuan literasi sains kurang baik yaitu nilai $<3$ dari skala 1-4. Banyak kendala yang dihadapi siswa tersebut, seperti keterbatasan HP dan kuota internet serta kurangnya pendampingan dari orang tua. Berdasarkan data, memang latar belakang kondisi ekonomi masing-masing siswa di tiga sekolah ini sangat beragam. Hal ini tentu memperngaruhi motivasi siswa dalam mengikuti program pembelajaran daring. Lingkungan keluarga yang mendukung terutama orang tua dan juga fasilitas belajar yang memadai sangat berpengaruh terhadap motivasi siswa dalam belajar. Seperti dalam penelitian yang dilakukan oleh Mulyani (2021) bahwa ada kontribusi positif dan signifikan antara lingkungan keluarga dan fasilitas belajar terhadap motivasi belajar siswa.

Selain dari sektor siswa, kesiapan guru juga berpengaruh terhadap terlaksananya pembelajaran tematik dan saintifik. Hanya 20\% guru yang menerapkan langkah saintifik secara berurutan dalam pembelajaran tematik. Sedangkan $80 \%$ guru menerapkannya sesuai topik yang dominan dibahas pada pertemuan itu. Sehingga implikasinya terhadap kemampuan siswa juga tidak optimal. Model-model pembelajaran yang digunakan guru juga terbatas disesuaikan dengan kondisi siswa.

Berdasarkan data tersebut, dapat ditemukan bahwa kemampuan literasi siswa di tiga SD dan MI di kabupaten Sumenep masih rendah yaitu sebanyak 71,7\% siswa. Hal ini disebabkan oleh pelaksanaan pembelajaran disekolah secara tematik saintifik tidak terlaksana dengan baik selama pandemi berlangsung.

Hasil ini kemudian peneliti crosscheck kembali kepada 6 orang guru yang secara berkala mengamati perkembangan literasi sains siswa. Guru menyatakan bahwa memang terjadi penurunan keaktifan siswa dalam pembelajaran selama pandemi, bila dibandingkan dengan pembelajaran sebelum pandemi. Misalnya keaktifan bertanya dan mendiskusikan materi atau tugas dari guru, juga kemampuan menganalisa data suatu kajian masalah. Guru melihat para siswa kurang bersemangat dalam pembelajaran daring. Hanya siswa-siswa tertentu saja yang mampu mengikuti alur

Vol. 13 No. 2 Juni 2021 
pembelajaran, yaitu siswa yang telah terbiasa dengan perangkat digital dan sarana daring lainnya. Juga siswa-siswa yang memiliki kemampuan belajar lebih dari siswa lain.

Data informasi dari penelitian ini dapat menjadi referensi bagi para guru Sekolah Dasar atau Madrasah Ibtidaiyah untuk lebih optimal dalam menerapkan Pendekatan Saintifik dan tematik Integratif dalam pembelajaran. Kemampuan guru dalam menggunakan model-model pembelajaran yang sesuai dengan saintifik juga harus ditingkatkan. Guru harus lebih kreatif dan inovatif. Harapannya adalah untuk meningkatkan kemampuan literasi sains siswa sebagai the next important skill yang harus dimiliki siswa agar mampu berprestasi di level pendidikan selanjutnya terlebih lagi masa mendatang dalam mengatasi masalah dalam kehidupannya.

\section{KESIMPULAN}

Hasil Penelitian ini menunjukkan bahwa di tengah masa pandemi dapat ditemukan adanya kemampuan literasi siswa di tiga sekolah dasar pada kabupaten Sumenep masih rendah yaitu sebanyak 71,7\% siswa, akibat berbagai kendala pembelajaran yang yang dilaksakanan dengan PJJ yakni (pembelajaran Jarak jauh), maka siswa memiliki problem seperti keterbatasan HP dan kuota internet serta kurangnya pendampingan dari orang tua. Berdasarkan data, memang latar belakang kondisi ekonomi sangat beragam. Hal ini tentu mempengaruhi motivasi siswa dalam mengikuti setiap program pembelajaran daring dan menyebabkan pelaksanaan pembelajaran disekolah secara tematik dan saintifik tidak terlaksana dengan baik selama pandemi berlangsung. Hasil ini juga sejalan dengan berbagai penelitian yang menunjukkan korelasi positif bila pembelajaran dilakukan dengan metode tematik dan saintifik yang dilaksanakan dengan baik, maka literasi sains siswa juga meningkat, sebelum masa pandemi datang.

Hasil penelitian ini, dengan metode yang digunakan tentunya bukan merupakan ketentuan absolut yang dapat berlaku dengan hasil yang sama untuk partisipan lain. Salah satu alasannya yaitu, ruang lingkup dari pokok pembahasan berada dalam spektrum tertentu, dan objek tertentu. Kajian terhadap ruang lingkup dan objek penelitian yang berbeda, akan menghadirkan simpulan yang berbeda pula. Karena itu, perlu dipahami bersama bahwa hasil dari penelitian ini merupakan gambaran yang masih perlu dilanjutkan dan perlu adanya kritik untuk penyempurnaan pada penelitian selanjutnya.

\section{REFERENSI}

Abdi, A. (2014). The Effect of Inquiry-based Learning Method on Students' Academic Achievement in Science Course. Universal Journal of Educational Research, 2(1), 37-41. https://doi.org/10.13189/ ujer.2014.020104

Arikunto, S. (2017) Prosedur Penelitian : Suatu Pendekatan Praktik. Jakarta : Rineka Cipta

Ain, N., \& Huda, C. (2018). Pendekatan Saintifik di Sekolah Dasar. Momentum: Physics Education Journal, 2(1), 1. https:/ / doi.org/10.21067/mpej.v1i1.2368

Antrock, J. W. (2011). Educational Psychology, Diana Angelica. Psikologi Pendidikan. Jakarta: Salemba Humanika

Abdul majid, (2014), Implementasi Kurikulim 2013. Kajian Teoritis dan Prkatis, (Bandung: Interes Media.

Vol. 13 No. 2 Juni 2021 


\section{MADRASAH}

Jurnal Pendidikan dan Pembelajaran Dasar

p ISSN: 1979-5599 | e ISSN: 2502-194X

Page

171

Abd. Kadir \& Hanun Asrohah, (2015) Pembelajaran Tematik, Jakarta: Rajagrafindo Persada 2015.

Ain, Nurul. (2018). Pendekatan Saintifik di Sekolah Dasar. Momentum: Physics Education Journal, 2 (1), 1-7

Argaw, A. S., Haile, B. B., Ayalew, B.T., and Kuma, S. G. (2017). The Effect of Problem Based Learning (PBL) Instruction on Students' Motivation and Problem Solving Skills of Physics.EURASIA Journal of Mathematics Science and Technology Education, 13(3):857871. http: doi.org/10.12973/eurasia.2017.00647a.

A Sujana et al. (2019). Science and mathematics literacy of elementary school students related to water cycle J. Phys.: Conf. Ser. 1318012131

Azrizal, dkk. (2018). Pengembangan Materi Instruksional Ilmu Pengetahuan Terpadu Untuk Meningkatkan Literasi Digital Siswa Dalam Pendekatan Ilmiah. Jurnal Pendidikan IPA Indonesia, 7 (4) 442-450.

Darmojo, H dan Kaligis, J.R.E. (1992). Pendidikan IPA 2. Jakarta: Depdikbud Dirjendikti.

Fauzia, N. L. U., \& Kelana, J. B. (2020). Natural Science Problem Solving in Elementary School Students Using the Project Based Learning (PjBL) Model. Jurnal Ilmiah Sekolah Dasar, 4(4). https://doi.org/10.23887/jisd.v4i4.28377

Hanafi. (2017). Konsep penelitian RED Dalam Bidang Pendidikan, (1989), 129-150.

Hurd, Paul deHart. (1998). Scientific literacy: New minds for a changing world. Science education, 82(3), 407-416. URL: https://dx.doi.org/10.1002/(SICI)1098237X(199806)82:3\%3C407::AID-SCE6\%3E3.0.CO;2-G

Jamilah, J. (2020). Guru profesional di era new normal: Review peluang dan tantangan dalam pembelajaran daring. Premiere Educandum: Jurnal Pendidikan Dasar dan Pembelajaran, 10(2), 238 - 247. Doi.org/10.25273/pe.v10i2.7494.

Karsai, I and Kempis, G. 2010. The Crossroads between Biology and Mathematics: The Scientific Method as the Basics of Scientific Literacy. BioScience. 60(8): 632-638.

Kelana, J. B., \& Pratama, D. F. (2019). Bahan Ajar IPA Berbasis Literasi Sains. Bandung: LEKKAS

Kelas, D. I., \& Babatan, V. S. D. N. (2020). MASALAH MELALUI MODEL PROBLEM BASED LEARNING. 03(04), 104-117.

Kemdikbud. (2016). Peraturan Menteri Pendidikan dan Kebudayaan Republik Indonesia Nomor 24 Tahun 2016 tentang Kompetensi Inti dan Kompetensi Dasar Pelajaran Pada Kurikulum 2013 pada Pendidikan Dasar dan Pendidikan Menengah. Jakarta Pusat: Kementerian Pendidikan dan Kebudayaan Republik Indonesia .

Mulyani, dkk. (2021). The Effect of Learning Facilities and Family Environment on Motivation to Learn of Prospective Elementary Teacher Education on Online Learning. Journal of Teching and Learning in Elementary Education (JTLEE). Department of Elementary Education Faculty of Teacher Training and Education, Universitas of Riau. Pekan Baru. DOI: http://dx.doi.org/10.33578/jtlee.v4i1.7866

Nafisah, Y.N dan Suyanto, W. (2014). Penerapan model pembelajaran problem-based learning, untuk meningkatkan keterampilan berpikir kritis dan prestasi belajar siswa. Jurnal Pendidikan Vokasi, 4(1): 125-143.

Nichols, A. J. and Stephens, A. (2013). The Scientific Method and the Creative Process: Implications for the K-6 Classroom. Journal for Learning through the Arts, 9(1):1-12.

Vol. 13 No. 2 Juni 2021

Madrasah homepage: http://ejournal.uin-malang.ac.id/index.php/madrasah/index 
Nisrina Hikmawati. (2020). Model Pembelajaran Kurikulum 2013 dalam Materi IPA Kelas 6 MI Miftahun Najah Desa Tenonan, Jurnal Kariman: Vol. 8 No. 1: Pendidikan dan Kesilaman. https:// doi.org/10.52185/kariman.v8i1.129

Rahmadona, \& Astimar. (2013). Implementasi Pendekatan Saintifik dalam Pembelajaran di Sekolah Dasar (SD). E-Buletin Media Pendidikan LPMP Sulsel, 4, 1-10.

Resor, Cynthia Williams, "Exploring Vacation and Etiquette Themes in Social Studies: Primary Source Inquiry for Middle and High School" (2017). EKU Faculty and Staff Books Gallery. 11.

Setiawan, A. R. (2019). Pembelajaran Tematik Berorientasi Literasi Saintifik. Jurnal Basicedu, 4(1), 51-69. https:/ / doi.org/10.31004/basicedu.v4i1.298

Setiawan, A. R. (2020). Desain Pembelajaran untuk Membimbing Siswa Sekolah Dasar dalam Memperoleh Literasi Saintifik. April 2020. https:/ / doi.org/10.35542/osf.io/u59f8

Setiawan, A. R., \& Saputri, W. E. (2020). Pembelajaran Literasi Saintifik untuk Pendidikan Dasar. Media Penelitian Pendidikan: Jurnal Penelitian Dalam Bidang Pendidikan Dan Pengajaran, 14(2), 144-152.

Sutmala, G. Y., \& Harni, H. (2020). Penerapan Pendekatan Saintifik Dalam Pembelajaran Tematik Terpadu Di Kelas II Sekolah Dasar (Studi Literatur). Journal of Basic Education Studies, 3(1), 114-128.https:/ / doi.org/10.26877/mpp.v14i2.5794

Syaifuddin, M. (2017). Implementasi Pembelajaran Tematik di Kelas 2 SD Negeri Demangan Yogyakarta. Tadris: Jurnal Keguruan Dan Ilmu Tarbiyah, 2(2), 139. https://doi.org/10.24042/tadris.v2i2.2142

Trianto. (2010). Pengembangan Model Tematik.Jakarta: Prestasi.PustakaKarya

Williamson, K., Given, L. M., \& Scifleet, P. (2017). Chapter 19. Qualitative data analysis. 417-439. http:/ / dx.doi.org/10.1016/B978-0-08-102220-7.00019-4

Xia, Jianping, (2020) Practical Exploration of School-Family Cooperative Education during the COVID-19 Epidemic: A Case Study of Zhenjiang Experimental School in Jiangsu Province, China. Available at SSRN: $\underline{\text { https:// ssrn.com/abstract }=3555523}$ or http://dx.doi.org/10.2139/ssrn.3555523

Vol. 13 No. 2 Juni 2021 